\title{
Az ultranagy-hatékonyságú folyadékkromatográfia határai
}

\author{
KORMÁNY Róbert $^{\mathrm{a}^{*}}$ és FEKETE Szabolcs ${ }^{\mathrm{b}}$ \\ ${ }^{a}$ Egis Gyógyszergyár Zrt., Keresztúri út 30-38., 1106 Budapest, Magyarország \\ ${ }^{b}$ University of Geneva, University of Lausanne, School of Pharmaceutical Sciences, \\ Group of Analytical Pharmaceutical Chemistry, CMU - Rue Michel Servet, 1, 1211 Geneva 4 - Switzerland
}

\section{Bevezetés}

Az analitikai vizsgálatok, így a nagyhatékonyságú folyadékkromatográfia (HPLC), egyik kulcsfontosságú kérdése, az elemzés időszükséglete. Az elemzési idő tulajdonképpen a mintaelökészítésre, a HPLC-s mérésre és az eredmény kiértékelésére szánt összes időszükséglet. A gyors folyadékkromatográfiás technikák megjelenése előtt az esetek döntő többségében a HPLC mérés időszükséglete volt a legnagyobb, tehát ez volt az elemzés sebességmeghatározó lépése. Ez különösen igaz a gyógyszeriparra, ahol egy szennyezésprofil vizsgálat során a hatóanyag mellett különböző kromatográfiás tulajdonsággal rendelkező szennyezőket kell minőségileg azonosítani és mennyiségileg meghatározni. A feladatot tovább bonyolítja, hogy a hatóanyag és szennyezők mennyiségében 4-5 nagyságrendnyi különbség lehet. Egy bonyolultabb elemzés, gyors folyadékkromatográfiás technikák alkalmazása nélkül, akár 1-2 órát is igénybe vehet. Ezzel szemben a mintaelőkészítés legtöbbször csupán egy beoldási lépésből és egy mechanikai tisztításból (szürés, centrifugálás) áll, a mérési adatok kiértékelésére pedig speciális szoftverek állnak rendelkezésre. A gyors folyadékkromatográfiás technikák megjelenésével, ugyanazon feladatnak a mérési ideje néhány percre csökkenthető ${ }^{1,2}$, vagyis már nem a HPLC mérés veszi igénybe a legtöbb időt az elemzés során. A gyors folyadékkromatográfia megvalósítási lehetőségeiröl számos szakcikk ${ }^{3-8}$ és összefoglaló munka ${ }^{8-10}$ született. Ezek közül szeretnénk kiemelni az utóbbi években, a témában magyar nyelven megjelent publikációkat, melyek a Magyar Kémiai Folyóirat hasábjain ${ }^{11,12}$ és könyv/könyvfejezet ${ }^{13-15}$ formájában jelentek meg.

Ebben az összefoglalásban a gyors folyadékkromatográfia egyik megvalósítási lehetősége, az ultranagy-hatékonyságú folyadékkromatográfia (UHPLC) alkalmazhatóságának korlátait szeretnénk bemutatni a mindennapi felhasználók számára.

\section{Az UHPLC technológia}

Mielőtt az UHPLC technika korlátairól beszélnénk, érdemes röviden összefoglalni, mit is jelent pontosan ez. Halász István és munkatársai elsők között mutatták meg, hogy elméletileg a folyadékkromatográfiában az elválasztás annál gyorsabb lehet, minél kisebb az állófázis (töltet) szemcseátméröje ${ }^{16}$. Arra is felhívták a figyelmet, hogy az elválasztás várható idejének a készülékek maximális müködtetési nyomása szab határt. 2004 mérföldkő volt a folyadékkromatográfia történetében, amikor a Waters cég forgalomba hozta az első $\sim 1000$ bar nyomáson működtethető, kis kolonnán kívüli térfogattal (rendszertérfogat) rendelkező folyadékkromatográfiás rendszerét ${ }^{3,4}$. A rendszer az UPLC ${ }^{\mathrm{TM}}$ nevet kapta, amely az Ultra Performance Liquid Chromatograph betüszava. Az elkövetkező években a legtöbb készülékgyártó szintén forgalomba hozta saját hasonló rendszerét. A szakirodalom összefoglaló néven ultranagy-hatékonyságú/nyomású kromatográfiának (Ultra-High Performance/Pressure Liquid Chromatography, UHPLC) nevezte el ezt a technikát.

Az UHPLC készülékekkel 1000 bar vagy afeletti (12001500 bar) nyomásesést érhetünk el, ami lehetővé teszi a $2 \mu \mathrm{m}$ alatti szemcseátmérőjü töltetes kolonnák használatát. Továbbá kis rendszertérfogatuk miatt pedig lehetőség van az állófázis méretének jelentős csökkentésére, lényeges hatékonyságvesztés nélkül.

A hatékonyságvesztést a folyadékkromatográfiában a zónaszélesedéssel tudjuk jellemezni, mely főleg a mozgófázis sebességétől, a komponens mozgó- és állófázisban mért diffúziós együtthatójától, visszatartásától, illetve a szemcseátmérőtől (állófázis morfológiájától) függ ${ }^{17}$. Amennyiben szemléltetni akarjuk a szemcseátmérő és a diffúziós tulajdonságok hatását az elválasztás hatékonyságára, akkor a van Deemter egyenlet következő egyszerüsített formáját írhatjuk fel ${ }^{18}$ :

$$
H=A \cdot d_{p}+f_{1}(k) \frac{D_{M}}{u}+f_{2}(k) \frac{d_{p}^{2} \cdot u}{D_{M}}
$$

Az összefüggésben $d_{p}$ a töltet szemcseátmérőt jelenti, $D_{M}$ pedig az adott komponens diffúziós együtthatóját. Az $f(k)$ a retenciós tényezőtől $(k)$ való függést jelöli. Az egyenlet sok elhanyagolást tartalmaz (pl. a diffúziós együttható nem azonos a szemcsék közötti folyadék fázisban és a szemcsén belüli stagnáló folyadékban, vagy az örvény-diszperzió a valóságban nem független a lineáris sebességtől, illetve az egyenlet nem különbözteti meg az anyagátadás álló- illetve mozgófázis járulékát), de első közelítésben jól szemlélteti, hogy az örvény-diszperzió egyenesen arányos a szemcseátmérővel, míg az anyagátadási tag a szemcseátmérö négyzetétől függ. Az egyenletből egyértelmüen következik, hogy a szemcseátmérő csökkentése jelentős tányérmagasság csökkenést (tányérszám növekedést) eredményez. Az 1. ábrán jól látszik, hogy a szemcseátmérö csökkentésével a tányérmagasság értéke is jelentősen csökkenthető, azaz nagyobb kinetikai hatékonyságot várhatunk ugyanolyan dimenziójú kolonnák esetén.

*e-mail: kormany.robert@egis.hu 


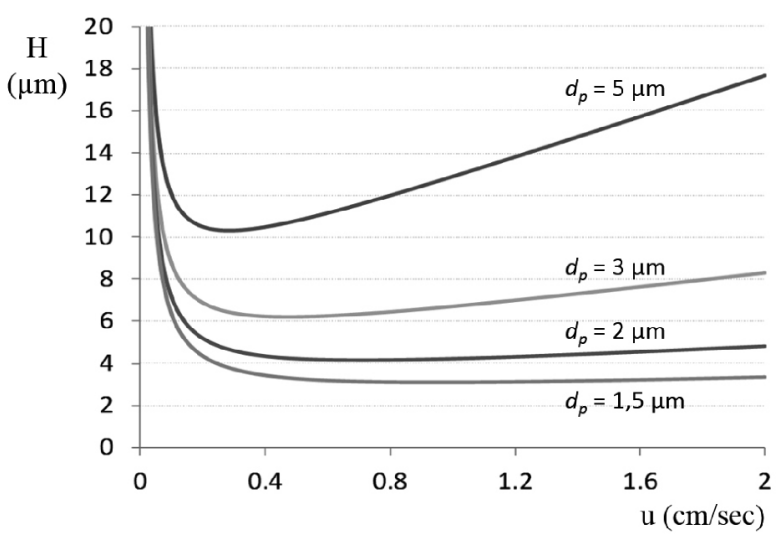

1. Ábra. Az elméleti tányérmagasság változása a lineáris áramlási sebességek függvényében, különböző szemcse-átmérőjü tölteteknél.

A szakirodalom elsődlegesen a kis szemcseátmérőt hangsúlyozza az elválasztások hatékonyságával kapcsolatban, holott a kis rendszertérfogat szorosan összefügg a gyorsasággal és a csúcsmaximumban mért koncentrációval ${ }^{19,20}$.

Egy UHPLC rendszerrel szemben két fő elvárásunk lehet, a nagy müködtetési nyomás tartomány ( 1000 bar), illetve a lehető legkisebb oszlopon kívüli térfogat okozta zónaszélesítő hatás.

Az első elvárás egyértelmű, minél nagyobb nyomáson tudunk dolgozni egy készülékkel annál több lehetőségünk van az elválasztás gyorsítására, illetve a kromatográfiás felbontás javítására. Folyadékkromatográfiás körülmények között, ahol a lineáris áramlási sebességek kicsik, az áramlás lamináris jellegü, ekkor a kolonnán létrejövő nyomásesés $(\Delta p)$ a Darcy-törvénnyel írható le.

$$
\Delta p=\frac{\Phi \cdot \eta \cdot L \cdot u}{d_{p}^{2}}
$$

$\mathrm{Az}$ egyenlet egyik fontos következménye, hogy a szemcseátmérö $\left(d_{p}\right)$ csökkenésével a nyomásesés négyzetesen növekszik. Ennek megfelelöen, ha $5 \mu \mathrm{m}$ helyett 1,7 $\mu \mathrm{m}$ szemcseátméröjü töltetet alkalmazunk, ugyanolyan dimenziójú kolonnában, ugyanolyan körülmények között, a nyomásesés akár kilencszeresére is nőhet. Tehát a szemcseátmérő csökkentésének nagymértékben határt szab a készülék maximális nyomás teljesítménye. A nyomásesés egyenes arányban változik a mozgófázis viszkozitásával $(\eta)$, ezért fontos, hogy a kis szemcseátmérőjü töltetekhez kis viszkozitású mozgófázist válasszunk, illetve szintén egyenesen arányosan függ a kolonna hosszától $(L)$ és a mozgófázis lineáris áramlási sebességétől $(u)$. A (2) egyenletben szerepel még a $\Phi$, ami a kolonna áramlási ellenállása.

A második elvárás kicsit összetettebb, kompromiszszumokból tevődik össze. A gyors elválasztás hatékonysága nemcsak a kolonnán múlik, hanem a kolonna hatékonyságának megtartásán is. Ezt az oszlopon kívüli térfogat csökkentésével tehetjük meg. Annál jobb egy készülék, minél kisebb az általa okozott oszlopon kívüli zónaszélesedés. Az oszlopon kívüli káros, hatékonyság rontó hatások annál jelentősebbek, minél kisebb a kolonna mérete.
A kromatogramon mért zónaszélesedés két fö részből tevődik össze, az egyik a kolonnán létrejövő, a másik a kolonnán kívüli. Ezért a kromatogramon mért zónaszélesedés (variancia, $\sigma^{2}$ total) a kolonnán és azon kívüli hatásokból tevődik össze:

$$
\sigma_{\text {total }}^{2}=\sigma_{e c}^{2}+\sigma_{c o l}^{2}
$$

ahol $\sigma_{c o l}^{2}$ és $\sigma_{e c}^{2}$ jelentik a kolonnán és a kolonnán kívüli zónaszélesedésre jellemző varianciát.

Az adagolóban és az összekötő vezetékekben azért van zónaszélesedés, mert az áramlás lamináris és a sebességi profil parabolikus. A molekulák, melyek a cső falához közelebb vannak lényegesen lassabban haladnak, mint a középső rétegben lévők. Azonban az áramló rétegek között a keveredés nem elhanyagolható, így a molekulák - a cső hosszától, átmérőjétől és áramlási sebességtől függően - a kapillárisok keresztmetszetét többször is átjárhatják. Ezt a jelenséget általában áramlási csúcsdiszperziónak hívjuk. Az összekötő vezetékekben létrejövő zónaszélesedés nagyban függ a vezeték átmérőjétől és hosszától. A kolonnán kívüli zónaszélesedés a következö összefüggéssel írható fel:

$$
\sigma_{e c}^{2}=\sigma_{i m j}^{2}+\sigma_{c a p}^{2}+\sigma_{\mathrm{det}}^{2}
$$

ahol $\sigma_{\text {inj }}^{2}$ a mintaadagoló, $\sigma_{\text {cap }}^{2}$ az összekötő vezetékek, $\sigma_{\text {det }}^{2}$ a detektorcella hozzájárulását fejezi ki a kromatogramon létrejövő zónaszélesedéshez.

Megállapodás szerint az oszlopon kívüli zónaszélesítő hatások összege nem lehet nagyobb, mint a kolonnán mért csúcsszélesedés tizede (ami 10\% látszólagos hatékonyság csökkenésnek felel meg).

$$
\sigma_{e c}^{2} \leq 0,1 \cdot \sigma_{c o l}^{2}
$$

Az oszlopon kívüli zónaszélesedésre hatással van még a térfogat-áramlási sebesség, a minta diffúziós tulajdonsága, a mozgófázis viszkozitása, a hőmérséklet és az injektált minta mennyisége. Megjegyezzük, hogy a detektált (látszólagos) csúcsszélességet befolyásolhatja még a detektor mintavételi frekvenciája, illetve időállandója is amennyiben az adatgyüjtés zajszüréssel van kombinálva.

\section{Megmaradó hatékonyság}

Az előző pontban leírtak alapján tehát, minél kisebb a kolonna térfogata és a komponens visszatartása, illetve minél hatékonyabb a kolonna, úgy válik egyre kritikusabbá az oszlopon kívüli csúcsszélesítő hatás. Bevezethetjük a látszólagos tányérszám $\left(N_{\text {app }}\right)$ fogalmát, ami felírható a kolonna által teljesített saját tányérszám $\left(N_{c o l}\right)$ és az oszlopon létrejövő illetve azon kívüli varianciák viszonyával.

$$
N_{a p p}=N_{c o l} \frac{\sigma_{c o l}^{2}}{\sigma_{c o l}^{2}+\sigma_{c c}^{2}}
$$


Az ún. megmaradó kolonna hatékonyság $\left(E_{r}\right)$ a következő módon adható meg:

$$
E_{r}=100 \frac{\sigma_{c o l}^{2}}{\sigma_{c o l}^{2}+\sigma_{e c}^{2}}
$$

A következő példában különböző (4,6, 3, 2,1 és $1 \mathrm{~mm}$ ) belső átmérőjű $50 \mathrm{~mm}$ hosszúságú kolonnák $(1,7 \mu \mathrm{m}$ töltet szemcseátmérő) megmaradó hatékonyságát mutatjuk be az oszlopon kívüli variancia függvényében $(k=5$ visszatartást feltételezve). A 2. ábrán jól látható, hogy a 4,6 mm átmérőjü kolonnákat használhatjuk bármilyen készülékben anélkül, hogy a látszólagos hatékonyság csökkenne.

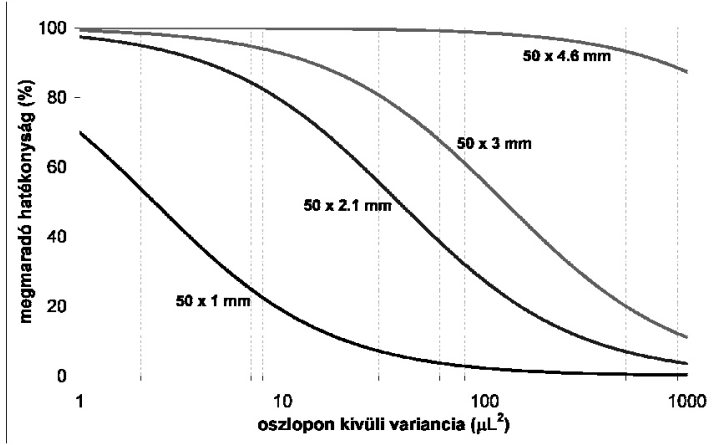

2. Ábra. Megmaradó hatékonyság az oszlopon kívüli variancia függvényében, 50 × 4,6, 50 × 3, 50 × 2,1 és 50 × 1 mm kolonna dinmenziókra (1,7 $\mu \mathrm{m}$ szemcseátmérő).

Hagyományos HPLC készülékek általában $\sigma_{e c}^{2}=40-200$ $\mu \mathrm{L}^{2}$ varianciával járulnak hozza a csúcsszélesedéshez, míg az UHPLC készülékek esetében ez csupán $\sigma^{2}{ }_{e c}=4-9 \mu \mathrm{L}^{2}$. Azok a készülékek, amelyeket a gyártók mind a hagyományos HPLC-s, mind pedig az UHPLC-s elválasztásokhoz javasolják (ún. hibrid készülékek) általában $\sigma_{e c}^{2}=10-40 \mu \mathrm{L}^{2}$-tel járulnak hozzá a csúcs szélesedéséhez. A 2011-ben megjelent UHPLC készülék (Waters UPLC I-Class) oszlopon kívüli varianciája, a mérés körülményeitöl függően $\sigma_{e c}^{2}=0,5-4 \mu \mathrm{L}^{2}$ közé esik. Tehát a legkorszerübb UHPLC készülékeket alkalmazva is jelentős hatékonyságot veszthetünk elsősorban $1 \mathrm{~mm}$ és $2,1 \mathrm{~mm}$ átmérőjü kolonnák esetén, nem tudjuk kihasználni a jelenlegi kolonnatechnológia valódi lehetőségeit. Jó kompromisszumnak tünik a 3 mm-es átmérőjű kolonnák használata. Persze ekkor az analízis idő rovására tudjuk csak a hatékonyságot fokozni.

\section{Az ultranagy-nyomás hatásai az UHPLC rendszerekben}

A következőkben felsorolásszerüen nézzük meg, hogy milyen paraméterekre van hatása, illetve milyen tulajdonságokat változtat meg a folyadékkromatográfiás rendszerben az ultranagy ( 1000 bar) nyomás alkalmazása:

- Állófázis térfogat

- Hőeffektusok (hossz- és keresztirányú hőgradiens)

- Diffúziós együttható folyadékokban

- Fázisarány

- Kétfázisú rendszerek egyensúlyi állandója

- Mozgófázis olvadás- és forráspont
- Mozgófázis dielektromos állandó

- Mozgófázis fajlagos térfogat (kompresszibilitás)

- Retenció

- Viszkozitás

- Sürüség

Terjedelmi okok miatt nincs lehetőség az összes paraméterváltozás hatásának bemutatására, ezért csak a gyakorlat számára a legfontosabbakat említjük meg.

\subsection{Hőeffektusok}

Az UHPLC rendszerek esetén nem hanyagolható el az a tény, hogy a nagy nyomással bevitt energia hővé alakul, amely eredményeképpen kereszt- és hosszirányú hömérséklet gradiens alakul ki a kolonnán ${ }^{21,22}$.

A kolonnatermosztát kialakítására két lehetőség van. Az egyik az ún. légkeveréses termosztát (forced-air), a másik pedig az ún. légmozgatás nélküli termosztát (still-air).

A légkeveréses termosztát esetén a kolonna fala állandó hőmérsékleten van tartva, ami keresztirányú hőmérséklet gradiens létrejöttének kedvez (3/a) ábra). Ez esetben a kialakuló keresztirányú hőmérséklet gradiens hozzáadódik a nyomás által keltett hosszirányú hőmérséklet gradienshez. Ezzel szemben a légmozgatás nélküli termosztátban gyenge a hőátadás a kolonna fal és környezete között, ennek következménye, hogy a keresztirányú hömérséklet gradiens nem lesz jelentős a hosszirányú hőmérséklet gradienshez képest $(3 / b)$ ábra). A gyakorlatban - a legtöbbször - a keresztirányú és hosszirányú hőmérséklet gradiens valamilyen arányú kombinációjával kell számolnunk. A 3. ábra sematikusan mutatja a kereszt- és hosszirányú hőprofilokat. A keresztirányú hőmérséklet gradiens elsősorban hatékonyság romlást, míg a hosszirányú hőmérséklet gradiens retencióváltozást eredményez. Keresztirányú hőmérséklet gradiens során a kolonna fal közelében alacsonyabb a hőmérséklet $\left(T_{f a l}\right)$, mint az oszlop középvonalában $\left(T_{C}\right)$. A középvonal menti magasabb hőmérséklet következménye még a gyorsabb molekuláris diffúzió, a kisebb mozgófázis viszkozitás $\left(c_{C}\right)$ és a megoszlási hányadosok különbsége a középvonal és a fal között. Ezek együttes hatásaként a mérendő komponensek a középvonal mentén gyorsabban haladnak, mint a fal közelében. Az áramlási profil torzul, amelynek eredménye, hogy széles kromatográfiás csúcsot kapunk.
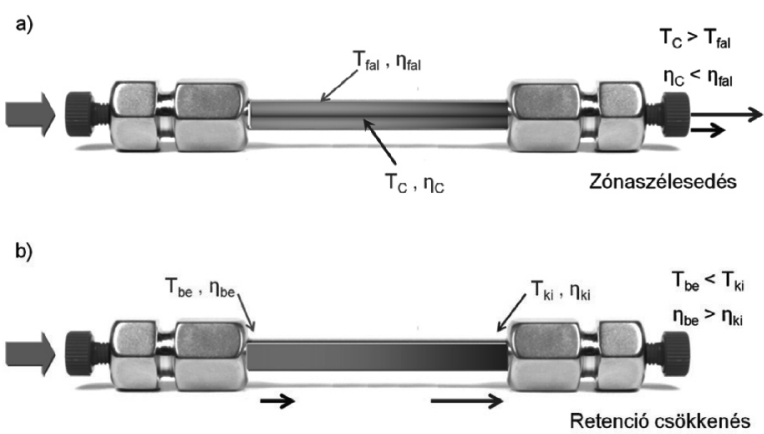

3. Ábra. Az oszlopban létrejövő keresztitányú a) és hosszirányú b) hőmérséklet gradiensek. 
A hosszirányú hőmérséklet gradiens következtében pedig az oszlop végénél mindig magasabb lesz a hőmérséklet $\left(T_{b e}\right)$ mint a bemenetnél $\left(T_{k i}\right)$. Az oszlop elején a nagy áramlási ellenállás miatt nagy mechanikai energiát kell befektetni a mozgófázis áramoltatásához. Az oszlop hossza mentén csökken a nyomás, a mechanikai energia hővé alakul és disszipálódik. Ez azt eredményezi, hogy általában az oszlop hossza mentén egyre gyorsabban haladnak a komponensek mivel egyre magasabb hőmérsékletü mozgófázisba érkeznek. Minél nagyobb a hosszirányú hőmérséklet gradiens, annál jelentősebb lesz a retenció csökkenés.

A hőátadás mértéke a környezet felé elsősorban a kolonna átmérőjétől függ, minél kisebb a kolonnaátmérő, annál nagyobb az egységnyi kolonnatérfogatra jutó hőátadó felület. Ebből következik, hogy ekkor inkább a 2 mm vagy a körüli belső átmérőjü, vagy az alatti kolonnák alkalmazása teszi lehetővé, hogy ne alakuljanak ki olyan hőmérséklet különbségek, amelyek jelentős csúcsszélesedést vagy retencióváltozást okoznak. A belső átmérő csökkentésével viszont jelentős mértékủ retenciós térfogat és csúcs-térfogat csökkenés következik be. Ekkor elötérbe kerülnek a kolonnán kívüli zónaszélesítő hatások és az abból eredő, korábban leírt készülék problémák.

\subsection{Mozgófázis fajlagos térfogat}

Érdekes gyakorlati következménye lehet annak, hogy a folyadékok nagy nyomáson kompresszibilisek. Mit is jelent ez? A légköri nyomáshoz képest, a víz fajlagos térfogata 1000 bar nyomáson 4 \%-kal lesz kisebb. Az acetonitril esetében ez a változás még jelentősebb, körülbelül $8 \%$. A metanol esetében $10 \%$ is lehet ez a térfogat változás (4. ábra). Érdemes megjegyezni, hogy a kompresszibilitás mértéke enyhén csökken a nyomás növelésével (nem lineáris összefüggés) és függ a hömérséklettől is.

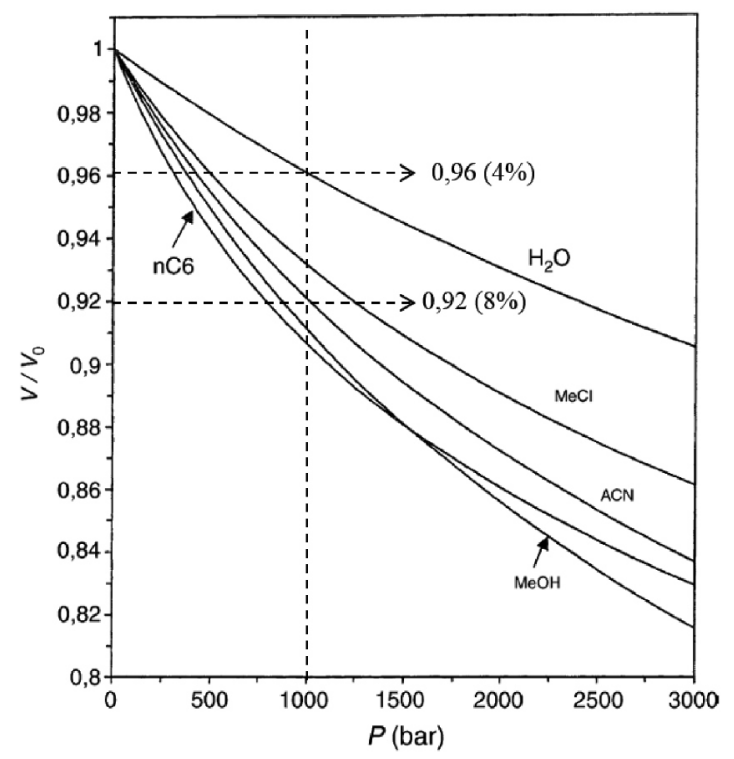

4. Ábra: Oldószerek fajlagos térfogatának változása a nyomás függvényében ${ }^{23}$.
A mozgófázis fajlagos térfogat változásának (kopresszibilitás) következménye, hogy a nyomással együtt változik az oszlopunk látszólagos holtideje, illetve holttérfogata. Egy 50 x 2,1 mm-es kolonnán, ha folyamatosan növeljük a térfogatáramot és ezzel együtt ugye a nyomást is, akkor 0 és 1000 bar között körülbelül 6-10\% látszólagos oszloptérfogat változást figyelhetünk meg. Felmerülhet a kérdés, hogy akkor mennyi is valójában a holttérfogat, illetve a mozgófázis valódi térfogatárama? A valódi térfogatáram attól függ, hogy a készülék melyik részén mérjük. Az 5. ábrán a folyamatos vonal jelzi a rendszeren eső nyomást, míg a szaggatott vonal jelzi a fajlagos térfogat változását a készülék különböző helyein $(z)$. Ezért nyilván, ha egy adott helyen szabályozzuk a térfogatáramot és nagy nyomáson dolgozunk, akkor a készülék más pontján más lesz a térfogatáram (lásd: $F_{1}, F_{2}$ és $F_{3}$ térfogatáramokat az 5. ábrán). Nagyon nem mindegy, hogy a készülékünk az oszlop előtt vagy után méri/szabályozza az áramlást. Ebből nagy különbség szokott adódni pl. Agilent és Waters SFC rendszerek esetén, ami jelentősen befolyásolhatja a módszertranszfert is. A korszerü készülékek legtöbbje már figyelembe veszi a mozgófázis kompresszióját és korrigálják a valódi beállításokat.

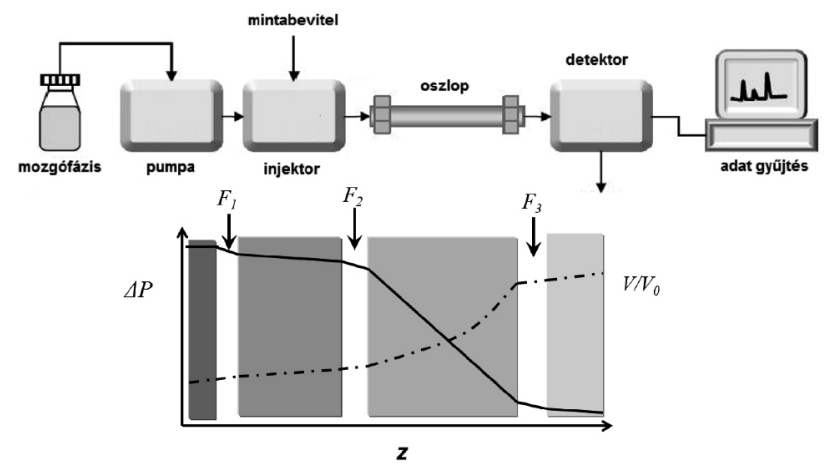

5. Ábra: A nyomásesés változása $(\Delta P)$ és a mozgófázis fajlagos térfogatának változása a folyadékkromatográfiás rendszerben.

\subsection{Mozgófázis viszkozitás}

A fajlagos térfogathoz hasonlóan a folyadékok viszkozitása is függ a nyomástól. A víz az egyetlen kromatográfiában használatos oldószer aminek a viszkozitása szinte alig változik a nyomással de a szerves oldószerek viszkozitása jelentősen nő a nyomás függvényében. A 6 . ábrán néhány gyakori oldószer viszkozitás változását láthatjuk a nyomás függvényében. Légköri nyomáshoz képest az acetonitrilnek 1000 bar nyomáson 1,6-szorosra nő a viszkozitása. Miért érdekes ez a viszkozitás változás? Azért mert a mérendő komponensek diffúziós állandója függ a közeg viszkozitásától, illetve az oldószer oldóereje valamint a folyadékok elegyíthetősége is változik a viszkozitással. Közvetett módon tehát a viszkozitás változása befolyásolhatja mind a retenciót, mind a csúcsszélesedést. 


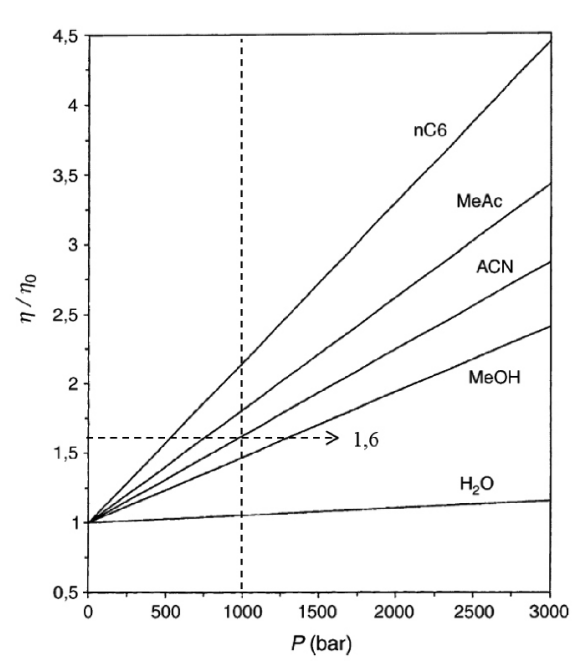

6. Ábra. Oldószerek viszkozitásának változása a nyomás függvényében ${ }^{23}$.

\subsection{A nagy nyomás közvetlen hatása}

Folyadékkromatográfiában gyakran használjuk az általános Gibbs szabadenergia egyenletet a parciális moláris térfogatváltozás leírására amikor a komponensünk hidrofób állófázison kötődik meg. Az összefüggés leírja a kapcsolatot a visszatartás és nyomás között. Az is kiderül az összefüggésböl, hogy elsősorban nagy molekuláknál van jelentős hatása a nyomásnak a retencióra, de megfelelöen nagy nyomáson dolgozva már kis molekuláknál is megfigyelhető a változás. Az összefüggés értelmében a nyomás növeléssel általában retenció növekedés várható. Az esetben ha légmozgatás nélküli oszlop termosztáttal dolgozunk, akkor a hosszirányú högradiens okozta retenció csökkentő hatás kompenzálhatja a nyomás által előidézett retenció növekedést és a hatás rejtve maradhat. Viszont légmozgatásos termosztátot alkalmazva 500-600 bar nyomás felett dolgozva már jól kimutatható a nyomás okozta retenció növekedés, szokásos kis molekulák kromatografálása során is.

Különösen érdekes lehet a nyomás hatása, ha ionizálható komponenseket (pl. bázisok) akarunk elválasztani. Ekkor a nyomás közvetlen retencióra gyakorolt hatása (a) és a súrlódás okozta hőhatások (b) mellett még a nyomás mozgófázis pH-ra (c) és a komponensek disszociációs állandójára (d) gyakorolt hatását is megfigyelhetjük. Mivel a különböző komponenseknél a négy említett hatás egyedi járuléka más és más, összességében jelentősen eltérő szelektivitást és felbontást kaphatunk nagy nyomáson dolgozva ${ }^{24}$. Erre mutat példát a 7 . ábra.

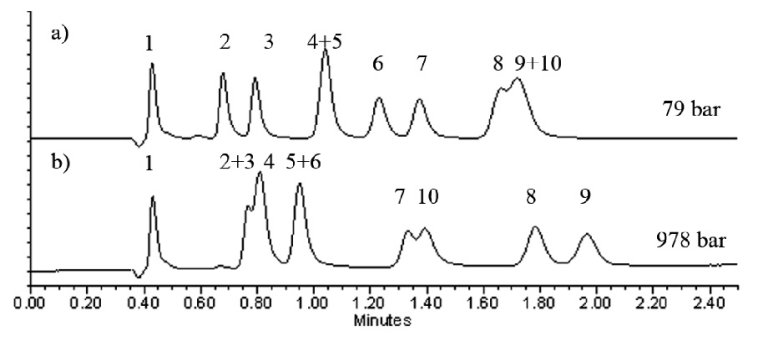

7. Ábra. Szelektivitás változása a nyomással UHPLC rendszerben (áramlási sebesség: 0,3 mL/perc). Állófázis: XBridge C18 50 x 2,1 mm, 5ěm, a) oszlop fojtás nélkül, b) oszlop fojtással. Minta: bázikus komponensek keveréke: 1) tiokarbamid, 2) 2-metil-benzil amine, 3) piridin, 4) 2,6-dimetil piridin, 5) 2-metil piridin, 6) 2,4-dimetil piridin, 7) 3-metil piridin, 8) anilin, 9) benzil alkohol, 10) 3,4-dimetil piridin.

\section{Módszertranszfer problémák}

Egy másik kérdéskör, ami szorosan kapcsolódik a készülék térfogathoz, az ún. gradiens késési vagy gradiens késleltetési idö/térfogat. Manapság a legtöbb folyadékkromatográfiás elválasztást (mind ipari, mind akadémiai laboratóriumokban) gradiens elúciós módban végzik (a mozgófázisban az erősebb „B” oldószer (acetonitril vagy metanol) koncentrációját növeljük az idő függvényében, ezáltal csökken a nagyobb megoszlási hányadossal rendelkező komponensek retenciója). Gradiens elválasztásoknál döntő jelentősége lehet a készülék gradiens késési térfogatának (dwell volume, $V_{d}$ ). Ez a térfogat a pumpa térfogatokból, keverőből, mintaadagoló hurokból (sample loop) és az oszlop elejéhez vezető összekötő kapillárisból tevődik össze és azt a „plussz időt” adja a rendszerhez, amíg a beállított mozgófázis összetétel a kolonna elején megjelenik. Ez a gradiens késési térfogat igen különböző lehet, attól függően, hogy ún. kis nyomású- vagy nagy nyomású keverő rendszerrel dolgozik a készülékünk. Konvencionális HPLC készülékeknél általában 0,5-2 mL között változik a gradiens késési térfogat a nagynyomású keverő rendszerek esetén, illetve $V_{d}=1-5 \mathrm{~mL}$ a kisnyomásúakra. A korszerü UHPLC készülékek tipikusan $0,08-0,5 \mathrm{~mL}$ gradiens késési térfogattal rendelkeznek. Készülékünk gradiens késési térfogatát ismerni kell, elsősorban módszerek átvételekor és átadásakor (transzfer) lehet nagy jelentősége. Gyakori a gyógyszeranalitikában, hogy régebbi, meglevő konvencionális HPLC módszereket transzferálunk UHPLC módszerré vagy éppen az ellenkezője, hogy az UHPLC módszereket kell hagyományos oszlopra/készülékre átdolgozni, mert az átvevő laboratóriumban csak az áll a rendelkezésre. Vegyünk egy egyszerü példát. UHPLC-ben tipikusan 0,5 $\mathrm{mL} /$ perc térfogatárammal dolgozunk. Ekkor, ha a készülékünk gradiens késési térfogata $0,5 \mathrm{~mL}$, akkor éppen 1 percet „késik” a gradiens program. Viszont ha $V_{d}=0,1 \mathrm{~mL}$ akkor csak 0,2 perc késésünk lesz. A két készüléken mért komponensek retenciós ideje között tehát 0,8 perc különbség várható. A kevésbé visszatartott komponensek esetén különösen kritikus lehet a gradiens késés változása. Sokszor a felbontás és néha még a szelektivitás is változhat (8. ábra).
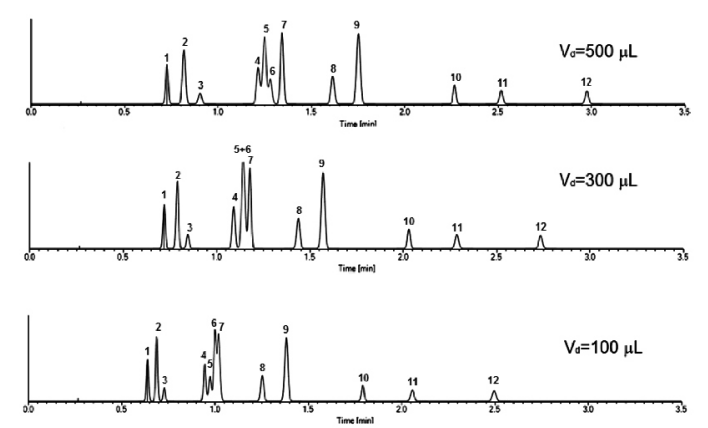

8. Ábra. A késleltetési térfogat hatása a retencióra.

A kis gradiens késleltetésű készülékeknél egy kezdeti izokratikus szakasz beikatatásával növelhetjük a „látszólagos” gradiens késést. A nagyobb gradiens késleltetésű rendszerek esetén pedig a gradiens programot nem az elejétől, hanem a késének megfelelő időhöz tartozó kiindulási mozgófázis összetételtől kell indítani, ha azt akarjuk, hogy hasonlítson a kromatogram a kisebb 
késleltetésủ rendszeren mért kromatogramhoz. Módszertranszferálásnál pedig a szokásos ún. ,geometriai transzfer szabályok" mellett a gradiens késési idő és oszlop holt idő arányát $\left(t_{d} / t_{0}\right)$ kell állandó értéken tartani.

Nyilván a gradiens késést érdemes csökkenteni amennyire csak lehet, de a végtelen csökkentésnek határt szab az a tény, hogy ha nem áll rendelkezésre a mozgófázisok keveredéséhez megfelelö térfogat/idő akkor a nem tökéletes keveredés miatt a módszer reprodukálhatósága nem lesz megfelelö. Ez nagy térfogatáramoknál különösen kritikus lehet, pulzálás is felléphet.

\section{Meddig érdemes növelni a nyomást a folyadék- kromatográfiás alkalmazásokban?}

Elsőre ígéretesnek tűnik a müködtetési nyomáshatár kiterjesztése (1000 bar fölé is), hiszen elvileg lehetőséget ad nagy-felbontású elválasztások megvalósítására (pl. oszlopok sorba kapcsolásával). Igaz, ennek az ára a hosszabb analízis idő lesz. A nagy nyomáson történő elválasztás segítségével nyilvánvalóan gyors méréseket is végezhetünk, például egy nagy hatékonyságú kis térfogatú kolonnával - aminek még ha alacsony is a permeabilitása - nagy nyomáson, megfelelően nagy térfogatáramon tudunk dolgozni és így az elválasztás ideje 1-2 percre csökkenthető. Ezeket a lehetőségeket hamar felismerték.

Jorgenson és kollégái, illetve Milton Lee csoportja már a 90-es években úttörő munkát végzett, hiszen olyan kísérleti készülékeket építettek amelyekkel akár 4000 vagy 7000 bar nyomáson is tudtak dolgozni ${ }^{25-27}$. Igaz, ezek a készülékek csak alacsony térfogatáram elöállítására voltak képesek (ilyen nagy nyomás-teljesítmény mellett) de ez nem volt probléma, hiszen elsősorban kapilláris kolonnákkal dolgoztak (pl. $50 \mathrm{~cm}$ x $33 \mu \mathrm{m}$ ). A kolonnák $1-1,5 \mu \mathrm{m}$-es nem porózus szemcsékkel voltak megtöltve. A 9. ábrán 7100 bar nyomáson történő elválasztásra mutatunk be egy példát Jorgenson munkáiból.

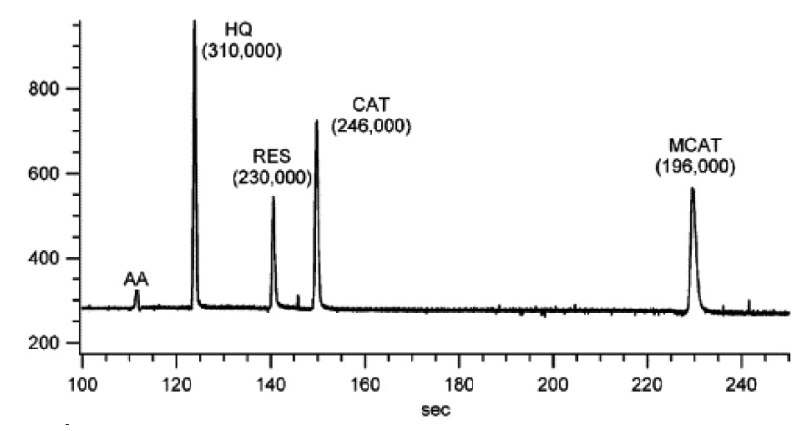

9. Ábra. Hidrokinon (HQ), rezorcinol (RES), katekol (CAT), és 4-metilkatekol (4-MCAT) kromatogramja. Aszkorbinsav (AA) a holtidőt jelző komponens. Kolonna: $43 \mathrm{~cm}$ x $10 \mu \mathrm{m}, 1 \mu \mathrm{m}$-es nem porózus szemcsékkel töltve. Az alkalmazott nyomás: 7100 bar. Az elméleti tányérszámok zárójelben feltüntetve ${ }^{27}$.

Nemrég Broeckhoven és kollégái már 2,1 mm átmérőjü kolonnák üzemeltetésére alkalmas készüléket terveztek amely lehetővé teszi, hogy 2600 bar nyomáson dolgozzunk analitikai kolonnával ${ }^{28}$. A készülékkel akár négy db 15 cm-es kolonna is sorba kapcsolható és igen nagy tányérszámok érhetők el (pl. $\mathrm{N}>80$ 000, viszonylag elfogadható analízis idő mellett).
Persze a nyomás nem növelhető a végtelenségig. Láttuk az előző fejezetekben, hogy a sok előny mellett számos "káros mellékhatása" is van a nyomásnak. Ezek közül elsősorban a hőmérséklet gradienseket kell szemelött tartani, hiszen jelentősen ronthatják az elválasztás hatékonyságát és nagyban befolyásolja a retentciót, majd ezen keresztül a felbontást. Összességében a kromatográfiás felbontás nehezen prediktálható lesz, ha nagy nyomáson dolgozunk. A készülékek és mérések ismételhetősége is gyengébb lesz és rövidebb kolonna élettartam várható. Példának említenénk, hogy ha egy 50 x 2,1 mm-es, 1,7 $\mu \mathrm{m}$ szemcseméretü kolonnát akarunk 3000 bar nyomáson üzemeltetni, akkor egy légmozgatás nélküli termosztáttal ellátott készülékben $40{ }^{\circ} \mathrm{C}$-kal lesz melegebb a mozgófázis a kolonna végénél az elejéhez képest. Ez a $40{ }^{\circ} \mathrm{C}$-os hőmérséklet gradiens azt jelenti, hogy a szelektivitás folyamatosan változik az oszlop hossza mentén ahogy a komponensek vándorolnak és egyre magasabb hőmérsékletü mozgófázisba érnek.

Nagy felbontású vagy gyors kromatográfiás elválasztásokat nem csak nagy nyomáson végezhetünk. Nagy permeabilitású kolonnákat (pl. monolit kolonna vagy 3-5 $\mu \mathrm{m}$ szemcse-átmérőjü héjszerkezetü töltet) viszonylag alacsony nyomáson is tudunk nagy térfogatáram alatt müködtetni tehát gyors elválasztások megvalósítására alkalmasak. Magas hőmérsékleten dolgozva a mozgófázis viszkozitása jelentősen csökkenthető, így szintén elkerülhető a nagy nyomás.

Azt is érdemes megjegyezni, hogy 1-2 percnél gyorsabb rutin folyadékkromatográfiás mérésekre jelenleg nincs is igény. Így is már a mintaelőkészítés, az injektálási ciklus és az adatok feldolgozása/kiértékelése az analitikai munkafolyamat sebesség-meghatározó fázisa nem pedig a kromatográfiás elválasztás.

Úgy tünik, hogy a nagyfelbontású folyadékkromatográfiás elválasztásokban se lesz szükség a mainál lényegesen nagyobb nyomásra, hiszen ezek a mérések időigényesek. A tömegspektrometriás detektorok rutin szerü terjedése mellett nem lesz szükség 50000 vagy 100000 feletti tányérszámokra. Továbbá a multi-dimenzionális kromatográfiás elválasztások is lényegesen több információt szolgáltatnak mint egy egy-dimenziós (nagyfelbontású és időigényes) kromatográfiás mérés. Összességében tehát azt mondhatjuk, hogy egyelőre nincs szükség magasabb nyomásra, mint amit a mai gyakorlatban alkalmazunk (1000 - 1500 bar $)$, illetve a maiaktól hatékonyabb kolonnák sem várhatók a közeljövőben, hiszen a jelenlegi kolonnák hatékonyságát sem tudjuk kihasználni.

\section{Egyéb fejlesztések a folyadékkromatográfiában}

Az állófázisok és oszlopok fejlesztése folyamatosan végig kísérte a HPLC történetét. Szemléltetésként megemlítjük, hogy csak fordított fázisú oszlopból jelenleg több mint 1000 féle kapható a kereskedelmi forgalomban. Az oszlopfejlesztők rohamos ütemmel próbálkoznak mindig valamilyen új morfologiájú vagy egyedi állófázisú töltet ellőállításával. A teljesség igénye nélkül néhány érdekes példát szeretnénk röviden megemlíteni: 
- A lamináris áramlás és a keresztirányú diffúzió következtében az oszlop keresztmetszetében sugárirányban a komponens koncentrációja eltérö lesz. Továbbá a kolonna fal mellett az ún. falhatás miatt a komponens nagyobb sebességgel halad, mint az oszlop belső részeiben. A falhoz közeli töltetágyban viszont a töltet sürüség általában nagyobb, mint a kolonna közepén tehát ebben a régióban pedig a komponens valamivel lassabban fog haladni. A két hatás eredményeként az oszlop középvonalától mért különböző távolságokban a komponensek eltérő sebességgel haladnak így az oszlop végénél már egy jelentős zónaszélesedés és csúcstorzulás léphet fel. Shalliker és mtsai egy sajátos oszlop hardver segítségével lényegesen csökkenteni tudták a káros falhatást és az áramlási egyenlőtlenséget ${ }^{29}$. Az ún. ,aktív áramlási technológia” (active flow technology, AFT) név alatt két lehetőséget is kínálnak: Az egyik a ,párhuzamosan elválasztott áramlás" (parallel segmented flow, PSF), ahol egy PEEK gyürüt tartalmazó kimeneti frit segítségével megszabadulhatunk a fal közelében áramló mozgófázistól és csak a kolonna középvonalából kiáramló homogénebb folyadékáramot továbbítjuk a detektorba. A 10. ábra egy ilyen PSF frit-et szemléltet. A PSF koncepció kiterjesztése az ún. „függönyáramlás” (curtain flow, CF), ahol a kimeneti PSF illeszték mellé egy ún. „középponti injektálást” (central point injection) alkalmazunk, amivel elkerülhetjük, hogy a komponensünk a fal közeli töltet részbe jusson. Az AFT alkalmazásával 10-15\%-os hatékonyság növekedés érhető el. Jelenleg a Thermo cég forgalmaz AFT kolonnákat illetve illesztéket.

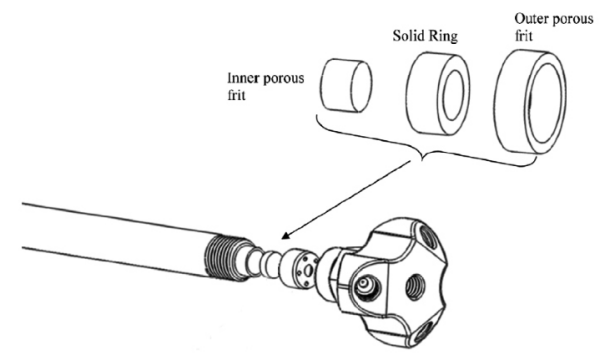

10. Ábra. PSF kolonna illeszték sematikus rajza ${ }^{29}$.

- Az ún. „,csúszás-áramlásos” kromatográfia (slip flow) is régóta fejlesztés alatt álló terület. A csúszás-áramlás akkor lép fel, ha nanocsatornák állnak a folyadék útjába. Ekkor a lamináris áramlás következtében kialakuló párhuzamosan áramló (eltérő sebességü) folyadékrétegek elcsúsznak egymáson és egy kevésbé torzult parabolikus áramlási profil alakul ki. Tehát csökken az áramlási egyenlőtlenség. Előállíthatjuk a jelenséget, ha egy kapilláris kolonnát néhány száz nanométer nagyságú szemcsével töltünk meg (pl. kolloid szilika).

- A héjszerkezetü, porózus és nemporózus töltetek előnyös tulajdonságait próbálja egyesíteni az ún. „gömb a gömbön” (sphere on sphere, SOS) kialakítású töltet szerkezet. A töltet magja egy néhány $\mu \mathrm{m}$ átmérőjü gömb (pl. $3 \mu \mathrm{m})$, amire aztán 10-100 nm nagyságú gömböket rögzítenek. A 11. ábra egy ilyen SOS töltet elektronmikroszkópos felvételét mutatja. Jelenleg makromolekulák elválasztásához tünik ígéretesnek, hiszen a nagy inert magnak köszönhetően a tölteten belüli lassú anyagátadás nem lép fel. Általában ez a folyamat a fő oka a makromolekulák csúcsszélesedésének. A felületre kötött nano-gömb felületek megfelelöen nagy fajlagos felületet biztosítanak. Itt jegyezzük meg, hogy az ionkromatográfiában évtizedek óta alkalmazott latex alapú állófázisok gyakorlatilag megfeleltethetők a modern ,gömb a gömbön" típusú állófázisoknak.

- Elméletileg előnyös olyan héjszerkezetü töltet előállítása is, amelyben a porózus rétegben kizárólag sugár irányú mezopórusok találhatók. Desmet és mtsai nemrég bemutatták, hogy lényegesen csökkenthető a hosszirányú diffúziú (a van Deemter egyenlet B-tagja) ilyen morfológiával, tehát elsősorban kismolekulák elválasztásánál lehet előnyös, főleg akkor, ha alacsonyabb térfogatáramon dolgozunk ${ }^{31}$.

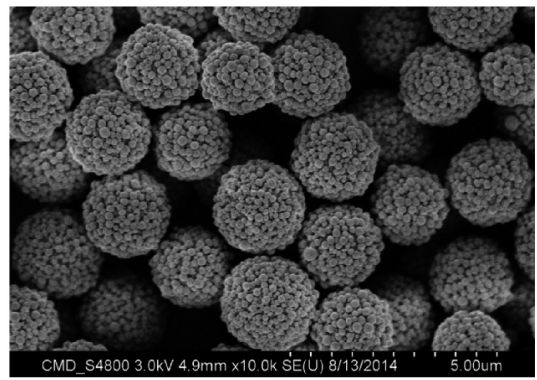

11. Ábra. SOS töltet elektronmikroszkópos felvétele ${ }^{30}$.

Említhetnénk még a különféle rendezett szerkezetü tölteteket (pl. pillar array) vagy azt, hogy jelenleg hogyan próbálunk megszabadulni a kellemetlen hőmérséklet gradiensektől (hőszigetelt kolonnák vákuumban vagy folyadékfürdőben) vagy akár azt, hogy egy trükkös injektálással hogyan lehet megszabadulni a kolonna előtti zónaszélesítő hatásoktól (POISe injektálás). A sok új ötletnek, fejlesztésnek mind ugyanaz a célja, nevezetesen hogyan tudunk még hatékonyabb folyadékkromatográfiás elválasztásokat végezni.

\section{Összefoglalás}

A közleményben ismertetett eredmények igazolják, hogy az ultranagy-hatékonyságú folyadékkromatográfiában (UHPLC) számos olyan paramétert figyelembe kell venni, amit a hagyományos nagyhatékonyságú folyadék- kromatográfiában (HPLC) elhanyagolhattunk vagy legalábbis kevésbé kellett vele számolni. Ilyen a készülék kolonnán kívüli térfogata (extra-column volume, $V_{e c}$ ) és késleltetési térfogata (dwell volume, $V_{d}$ ). Emellett nem hanyagolhatjuk el az akár 1000 bar környéki nyomásesésből eredő hatásokat sem. Ilyenek lehetnek a súrlódási energiából keletkező hőenergia vagy a fizikai-kémiai paraméter változások (pl. mozgófázis viszkozitás és fajlagos térfogat). Ezek a hatások nem csak a folyadékkromatográfiás rendszerünk hatékonyságát ronthatják le, de jelentősen befolyásolhatják a módszertranszfert az eltérő típusú rendszerek között, megnehezítve ezzel a gyakorló szakemberek munkáját.

A közlemény végén említésre kerül néhány speciális megvalósítási lehetőség is, melyek a jövő UHPLC megoldásait vetítik előre.

\section{Köszönetnyilvánítás}

A szerzők ezúton szeretnének köszönetet mondani Dr. Bobály Balázsnak, aki a cikk létrejöttéhez értékes szakmai tanácsaival, észrevételeivel járult hozzá. 


\section{Hivatkozások}

1. Kormány, R.; Molnár, I.; Fekete, J. J. Pharm. Biomed. Anal., 2017, 135, 8-15.

https://doi.org/10.1016/j.jpba.2016.11.050

2. Schmidt A.H; Molnár, I. J. Pharm. Biomed. Anal., 2013, 78-79, 65-74. https://doi.org/10.1016/j.jpba.2013.01.032

3. Swartz, M. E.; Murphy B. American Laboratory 2005, 37, 22-30.

4. Swartz, M. E. J. Liq. Chrom. Rel. Techn. 2005, 28, 1253-1263. https://doi.org/10.1081/JLC-200053046

5. Guillarme, D.; Ruta, J.; Rudaz S.; Veuthey J.-L. Anal. Bioanal. Chem. 2010, 397, 1069-1082. https://doi.org/10.1007/s00216-009-3305-8

6. Fekete, Sz.; Oláh E.; Fekete J. J. Chromatogr. A 2012, 1228, 57-71. https://doi.org/10.1016/j.chroma.2011.09.050

7. Fekete, Sz.; Veuthey J.-L.; Guillarme, D. J. Chromatogr. A 2015, 1408, 1-14. https://doi.org/10.1016/j.chroma.2015.07.014

8. Guillarme, D.; Veuthey, J.-L. (eds) UHPLC in Life Sciences, Royal Society of Chemistry, 2012. https://doi.org/10.1039/9781849735490

9. Xu, Q.A. (ed) Ultra-High Performance Liquid Chromatography and Its Applications, John Wiley \& Sons, Inc., 2013. https://doi.org/10.1002/9781118533956.ch9

10. Naushad, M.; Khan, M. R. (eds) Ultra Performance Liquid Chromatography Mass Spectrometry, CRC Press, 2014. https://doi.org/10.1201/b16670

11. Fekete, J.; Fekete, Sz. Magy. Kém. Foly. 2013, 119(1), 28-39.

12. Kormány, R. Magy. Kém. Foly. 2016, 122(2-4), 179-186.

13. Fekete, J.; Kormány, R.; Fekete, Sz. A folyadékkromatográfia fejlesztési irányai 2014, Merck Kft. ISBN 9789630894074

14. Sohár, P. (szerk.), A gyógyszerkutatás müszeres módszerei Fekete, J.; Kormány, R.; Fekete, Sz. I. fejezet: Folyadékkromatográfia 2015, Magyar Kémikusok Egyesülete http://real.mtak.hu/id/eprint/23335

15. Fekete, J.; Kormány, R.; Fekete, Sz. (szerk.) Modern folyadékkromatográfia 2017, KromKorm Kft. ISBN 978-963-12-8171-2

\section{Limits of ultra-high performance liquid chromatography}

This article reviews the current practice of analytical scale ultra-high pressure/performance liquid chromatography (UHPLC). UHPLC is now a standard tool to decrease the analysis time of conventional HPLC separations and applied routinely in pharmaceutical analytical laboratories. Extending the system pressure beyond the limit of 1000 bar appears as a powerful strategy to increase the maximal achievable efficiency in LC, and also the throughput. In UHPLC, the column dimension and the particle size of the packing material are decreased in order to reduce the retention volume and to improve the achievable plate numbers, respectively. Typical column dimensions are $50 \mathrm{x}$ $2.1 \mathrm{~mm}, 100 \times 2.1 \mathrm{~mm}$ and $150 \times 2.1 \mathrm{~mm}$ and columns packed often with sub-2 $\mu \mathrm{m}$ particles. This approach however requires very high pressure conditions as the permeability of columns decreases when deceasing the packing size. Therefore the mechanical stability of those columns had to be improved to be able to operate them in the $1000-1500$ bar pressure range.
16. Halász, I.; Endele, R.; Asshauer, J. J. Chromatogr. 1975, 12, 37-60. https://doi.org/10.1016/S0021-9673(00)99941-2

17. Knox, J. H.; Scott, H. P. J. Chromatogr. 1983, 282, 297-313. https://doi.org/10.1016/S0021-9673(00)91609-1

18. Villiers, A.; Lestremau, F.; Szucs, R.; Gélébart, S.; David, F.; Sandra, P. J. Chromatogr. A 2006, 1127, 60-69. https://doi.org/10.1016/j.chroma.2006.05.071

19. Guillarme, D.; Nguyen, D. T. T.; Rudaz, S.; Veuthey, J.-L. Eur. J. Pharm. Biopharm. 2007, 66, 475-482. https://doi.org/10.1016/j.ejpb.2006.11.027

20. Fountain, K. J.; Neue, U. D.; Grumbach, E. S.; Diehl, D. M. J. Chromatogr. A 2009, 1216, 5979-5988. https://doi.org/10.1016/j.chroma.2009.06.044

21. Neue, U.D.; Kele, M. J. Chromatogr. A 2007, 1149, 236-244. https://doi.org/10.1016/j.chroma.2007.03.042

22. Gritti, F.; Martin, M.; Guiochon, G. Anal. Chem. 2009, 81, 3365-3384. https://doi.org/10.1021/ac802632x

23. Martin M.; Guiochon G. J. Chromatogr. A 2005, 1090 16-38. https://doi.org/10.1016/j.chroma.2005.06.005

24. Fallas, M. M.; Neue, U. D.; Hadley, M. R.; McCalley, D. V. J. Chromatogr. A 2010, 1217, 276-284. https://doi.org/10.1016/j.chroma.2009.11.041

25. MacNair, J.E.; Lewis, K.C.; Jorgenson, J.W. Anal. Chem. 1997, 69, 983-989. https://doi.org/10.1021/ac961094r

26. MacNair, J.E.; Patel, K.D.; Jorgenson, J.W. Anal. Chem. 1999, 71, 700-708. https://doi.org/10.1021/ac9807013

27. Patel, K.D.; Jerkovich, A.D.; Link, J.C.; Jorgenson, J.W. Anal. Chem. 2004, 76, 5777-5786. https://doi.org/10.1021/ac049756x

28. Pauw, R.D.; Degreef, B.; Ritchie, H.; Eeltink, S.; Desmet, G.; Broeckhoven, K. J. Chromatogr. A 2014, 1347, 56-62. https://doi.org/10.1016/j.chroma.2014.04.056

29. Shalliker R.A.; Ritchie H. J. Chromatogr. A, 2014, 1335, 122-135. https://doi.org/10.1016/j.chroma.2013.08.004

30. Fekete S.; Rodriguez-Aller M.; Cusumano A.; Hayes R.; Zhang H.; Edge T.; Veuthey J.L.; Guillarme D.; $J$. Chromatogr. A, 2016, 1431, 94-102. https://doi.org/10.1016/j.chroma.2015.12.055

31. Derrider S.; Catani M.; Cavazzini A.; Desmet G.; J. Chromatogr. A, 2016, 1456, 137-144. https://doi.org/10.1016/j.chroma.2016.05.062

High pressure has impact on several properties of both the mobile phase and solutes. Frictional heating effects can be critical and decrease the apparent efficiency of the columns or impact retention and selectivity. In addition, the extent of developed thermal gradients depends on the design of the column oven therefore is instrument dependent. In systems using still-air oven, mostly longitudinal gradients are developed which tends to decrease solute retention and therefore selectivity can be changed. While in forced-air ovens, the radial temperature gradients are generally more dominant than the longitudinal ones which results in additional band broadening due to velocity (diffusion) differences developed in the cross section of the column. Beside friction, the specific volume, viscosity and density of the mobile phase are all affected by the pressure. These changes can obviously impact retention and peak width. The mobile phase compressibility occurring at high pressure changes the apparent flow rate and column volume therefore 
raises questions about the accurate flow-rate control. Current UHPLC systems take the compressibility into account and adjust the volumetric flow rate accordingly. However depending on the location of flow rate control (sensor can be positioned before or after the column) differences may happen in average flow rate between different systems. It may cause problems during method transfer.

The retention itself directly depends on the pressure. The dependence of retention factor $(k)$ of a compound on the pressure can be derived - generally - from the Gibbs free energy model - in reversed phase chromatography. The equation suggests that retention increases with pressure. The free energy model also suggests that the decrease of the partial molar volume upon adsorption on a hydrophobic surface is more important for large molecules than for small solutes. Please note that pressure itself and longitudinal temperature gradient (caused by friction) have antagonist effects therefore their overall effect sometimes remains hidden when using a system equipped with still-air oven.

Current UHPLC systems are not able to take the full benefits of state-of-the-art columns because of their important extra-column volume and extra-column dispersion. The column peak variance depends on the column volume and retention factor. Thus small columns are generally more sensitive for extra-column dispersion and peaks with low retention are especially critical. When using $50-2.1 \mathrm{~mm}$ very efficient columns, only the $60-80 \%$ of the intrinsic column efficiency can be attained on current instrumentation. The situation is much worse when working with $1 \mathrm{~mm}$ id columns. Much less than $50 \%$ of the column's true efficiency can be seen. UHPLC systems needs to be optimized when operating very efficient small columns. Users should replace the connection tubing and use the possibly narrowest (e.g. $0.065 \mathrm{~mm}$ id) and shortest ones before and after the column. On not-optimized UHPLC systems (e.g. possessing $\sigma_{e c}^{2}>10 \mu \mathrm{L}^{2}$ ), working with $3 \mathrm{~mm}$ id columns seems to be a good compromise between remaining efficiency and analysis time.

Due to the differences in dwell volumes of commercially available liquid chromatographic systems, method transfers often fail. Conventional HPLC systems with high-pressure mixers typically have dwell volume of $V_{d}=0.5-2 \mathrm{~mL}$, while low-pressure mixers contribute to $V_{d}=1-5 \mathrm{~mL}$. With modern UHPLC systems, this gradient delay volume ranges between 0.08 and $0.5 \mathrm{~mL}$. It is mandatory to know the system dwell volume especially when transfering a method between HPLC and UHPLC. The differences have to be taken into account and the gradient programs need to be adjusted/scaled to maintain the same quality of the separation. For that purpose, the ratio of dwell time and column dead time $\left(t_{d} / t_{0}\right)$ needs to be maintained.

Some possible future perspectives of liquid chromatography are also mentioned. Parallel segmented flow (PSF) chromatography offers to achieve higher efficiency based on the radial separation of flow layers. The flow from a PSF column elutes from either of two separated radial zones: The central flow region of the bed, which is separated from the peripheral or wall flow region. This is achieved by using an annular frit design, and a multi-channel end fitting.

Another interesting approach is the so-called slip flow chromatography. Slip flow is an important phenomenon in nano-fluidics, whereby flow enhancement is caused by weak interactions between the fluid and the wall. The flattening of the parabolic flow profile by slip flow promises an especially large impact on chromatography because the flow profile is the fundamental limitation to the reduction of band broadening.

The potential advantage of superficially porous particles with strictly radially-oriented meso-pores also seems to be promising. A significant increase in efficiency of these particles can be fully attributed to their much smaller B-term band broadening, while their $\mathrm{C}$-term band broadening (representing the mass transfer resistance) remains unaffected.

Other particle morphologies such as sphere on sphere particles (SOS) have also seen some applications recently. Due to the presence of a large inert sphere (the core sphere), this particle is especially advantageous for large molecules (proteins) which possess low diffusivity.

UHPLC today is one of the most applied analytical tools. Therefore continuous developments are expected from both system and column providers. Future applications will probably offer faster and more efficient separations that we can imagine today. 